\title{
PENINGKATAN KEMAMPUAN MEMBACA DAN MEMAHAMI TEKS BAHASA INGGRIS MELALUI TEKNIK SKIMMING- SCANNING PADA MAHASISWA STIT RU SEMESTER II 2017/2018
}

\author{
Fitri Susanty \\ Sekolah Tinggi Ilmu Tarbiyah Raudhatul Ulum Sakatiga \\ Email: fitrisusanty@stit-ru.ac.id
}

\begin{abstract}
Abstrak
Peningkatan Kemampuan Membaca Dan Memahami Teks Bahasa Inggris Melalui Teknik SkimmingScanning Pada Mahasiswa Semester II Di Sekolah Tinggi Ilmu Tarbiyah Raudhatul Ulum. Penelitian ini bertujuan: 1) menganalisis dan menemukan perencanaan pembelajaran Bahasa Inggris dengan mengunakan teknik skimming-scanning,2) menemukan dan menganalisis proses pelaksanaan pembelajaran Bahasa Inggris dengan mengunakan teknik skimming-scanning, 3) menemukan dan menganalisis evaluasi pembelajaran Bahasa Inggris dengan tepat menggunakan teknik skimmingscanning, 4) menemukan dan menganalisis peninkatan kemampuan membaca dan memahami tek Bahasa Inggris dengan menggunakan teknik skimming-scanning. Penelitian ini merupakan penelitian tindakan kelas yang terdiri dari 2 siklus. I dilakukan dengan teknik biasa, dansiklus II dilakukan dengan teknik skimming scanning. Pengumpulan data melalui observasi dan tes.Kesimpulan penelitian ini adalah: 1) menemukan dan menganalisis perencanaan pembelajaran Bahasa Inggris dengan mengunakan teknik skimming-scanning Siklus I menjelaskan kegiatan pembelajaran. Nilai rata-rata yang dihasilkan yaitu 6,5 atau dikategorikan cukup baik. Siklus 2 kegiatan pembelajaran difokuskan pada mensosialisasikan teknik membaca skimmingscanning untuk meningkatkan pemahaman membaca nilai rata-rata mencapai 8,5 kategori 2) peningkatan kemampuan membaca dan memahami siklus I yang tuntas mencapai 12 atau 50\% maha siswa dan nilai rata-rata 6,5, siklus kedua24 mahasiswa tuntas atau 100\% dan nilai rata-rata 8,5.
\end{abstract}

Kata Kunci: Kemampuan, Membaca, Memahami, Teknik Skimming-Scanning

\section{Pendahuluan}

Pembelajaran Bahasa Inggris merupakan salah satu mata pelajaran yang yang di ajarkan di sekolah / madrasah mulai dari tingkat terendah sampai perguruan tinggi. Bahasa inggris bukanlah sebuah mata pelajaran yang mudah untuk dipelajari apalagi bagi siswa yang masih dalam pendidikan dasar. Dalam bahasa inggris ada beberapa kemampuan yang harus dikembangkan, yaitu kemampuan mendengar (listening), menulis (writing), membaca (reading) dan berbicara (speaking). Kemampuan mendengar adalah kemampuan dimana siswa harus paham dengan apa yang diucapkan oleh native speaker. Untuk kemampuan menulis, adalah dimana siswa mampu menuliskan kata, kalimat ataupun cerita dalam bahasa inggris. Kemampuan berbicara adalah kemampuan dalam berkomunikasi dari apa yang telah mereka dengar dan tulis. Sedangkan kemampuan membaca merupakan 


\section{Peningkatan Kemampuan Membaca dan Memahami Teks Bahasa Inggris Melalui Teknik Skimming, Scanning Pada Mahasiswa STIT RU Semester II 2017/2018}

\section{Fitri Susanty}

kemampuan siswa memahami dan mengerti suatu kata, kalimat ataupun cerita, sehingga mereka bisa menceritakan kembali apa yang telah mereka baca.

Dalam kemampuan membaca, siswa dapat mendapatkan informasi, pengetahuan dan wawasan baru tentang sesuatu yang dapat meningkatkan kecerdasan siswa. Membaca sebuah teks tidaklah mudah, kita perlu membaca sekilas lalu intensif. Membaca sekilas bertujuan untuk mendapatkan informasi tentang isi bacaan, dan intensif diperlukan untuk memperoleh informasi yang lebih bermutu dan mendalam. Memahami bacaan tidaklah mudah karena itu berarti siswa perlu memahami ide pokok, dan isi bacaan. Oleh karena itu, siswa perlu memahami banyak kosakata dan struktur tulisan yang baik. Dengan demikian, keterampilan membaca bukanlah suatu keterampilan yang mudah. Perlu sebuah teknik atau metode untuk memahami sebuah bacaan dengan lebih mudah dan cepat.

Bahasa Inggris yang berfungsi sebagai alat pengembangan diri siswa dalam bidang ilmu pengetahuan, teknologi, seni dan pendidikan, secara khusus pada bidang pendidikan. Bahasa Inggris memiliki peran yang penting karena begitu banyak teks ilmu pengetahuan yang ditulis dalam bahasa Inggris. Pada kurikulum pendidikan di Indonesia, Bahasa Inggris merupakan mata pelajaran yang diajarkan mulai dari tingkat sekolah dasar sampai ke perguruan tinggi. Bahasa Inggris adalah salah satu mata pelajaran yang diikut sertakan dalam ujian nasional.

Unsur-unsur bahasa lainnya seperti kosa kata, tata bahasa, lafal dan ejaan dapat diajarkan untuk menunjang pengembangan keempat keterampilan berbahasa tersebut, bukan untuk kepentingan penguasaan unsur-unsur bahasa itu sendiri dan kemampuan pemahaman bacaan memegang peranan penting dalam mengembangkan keterampilan membaca.

Hasil uji kemampuan membaca dan memahami mahasiswa pada saat diadakan tes awal cukup baik, Menurut penuli rata-rata kecepatan membaca mahasiswa dalam bahasa Inggris sebagai bahasa asing adalah 120-150 kata permenit sedangkan kemampuan memahaminya hanya mencapai $50 \%$ sampai $70 \%$. Kenyataan di lapangan, terlihat banyaknya pengajar bahasa Inggris mengeluhkan rendahnya kemampuan membaca dan memahami teks bahasa Inggris. Kemampuan membaca dan memahami teks mahasiswa semester II pada mata kuliah Bahasa Inggris semester genap tahun pelajaran 2017/2018 hanya 50\% mahasiswa yang mendapat nilai tuntas.

Mahasiswa mengalami kesulitan dalam membaca dan memahami teks karena salah satunya kurang menguasai kosakata bahasa Inggris. Selain kemampuan mahasiswa dalam membaca dan memahami masih rendah, pengajar juga masih kurang mampu merencanakan pembelajaran. Ketika proses pembelajaran menuju ke aktifitas membaca mahasiswa cenderung menggunakan waktu yang sangat panjang untuk membaca sebuah teks.

Pembelajaran keterampilan membaca memerlukan salah satu teknik membaca cepat agar mahasiswa dapat membuat kesimpulan, memahami apa yang tersirat 
Volume 4 Nomor 1 Edisi Juni 2019

P-ISSN : 2541-3686

dalam bacaan dan dapat mengidentifikasi suatu bacaan dengan menggunakan waktu secara efektif dan efisien dengan hasil yang memuaskan.

Pemilihan teknik juga mempengaruhi kemampuan membaca dan memahami teks pada mahasiswa. Teknik pembelajaran skimming-scanning belum diterapkan di sekolah Tinggi Ilmu Tarbiyah Raudhatul Ulum. pengajar hanya memberikan bahan bacaan ataupun teks dengan penyediaan waktu yang banyak sehingga mahasiswa tidak terbiasa dengan teknik membaca cepat (skimming-scanning). Hal ini dapat mempengaruhi kemampuan membaca dan memahami para mahasiswa, serta tidak dapat menigkatkan kemampuan membaca dan memahami teks dengan cepat.

Keterampilan membaca dianggap lebih sulit dibandingkan keterampilan lain, karena meliputi beberapa komponen yang harus dikuasai siswa yaitu kosakata, pengucapan, pemahaman, structure sehingga perlu adanya kriteria penilaian yang mendetil seperti bagaimana mahasiswa dalam menemukan tema teks, ide pokok, informasi khusus, informasi rinci dan lain sebagainya.

Berdasarkan uraian diatas penulis melakukan penelitian mengenai "Peningkatan kemampuan Membaca dan Memahami Teks Bahasa Inggris melalui Teknik Skimming-Scanning pada Mahasiswa STITRU semester II TA 2017/2018". Mengingat alokasi waktu mata kuliah ini sangatlah terbatas, sehingga mahasiswa dapat menjadi pembaca yang efektif dan efisien.

\section{Tujuan Penelitian}

Berdasarkan rumusan masalah yang telah diuraikan di atas maka tujuan penelitian ini adalah untuk :

a. Menganalisis dan menemukan perencanaan pembelajaran Bahasa Inggris dengan mengunakan teknik skimming-scanning untuk meningkatkan kemampuan membaca dan memahami teks bahasa Inggris pada mahasiswa STITRU semester II TA 2017/2018

b. Menganalisis dan menemukan hasil pembelajaran Bahasa Inggris dengan menggunakan teknik skimmingscanning untuk meningkatkan kemampuan membaca dan memahami teks bahasa Inggris pada mahasiswa STITRU semester II TA 2017/2018

\section{Kajian Pustaka}

\section{Kemampuan Membaca Teks}

Membaca sangat penting bagi setiap orang karena hal itu akan mampu meningkatkan pengetahuan pengetahuan dan wawasan bagi mereka yang melakukannya. Namun, kegiatan membaca belum banyak dilakukan, sehingga upaya untuk membangun kesadaran untuk gemar membaca telah lama dilakukan dengan berbagai cara. Menurut Setiawan (2001:4) membaca adalah sebuah aktivitas.

Membaca adalah sebuah proses, yakni informasi yang berasal dari teks dan pengetahuan yang dimiliki pembaca untuk berinteraksi secara dinamis untuk menghasilkan sebuah makna. Howart (2006: 1) reading is just as communicative as any 


\section{Peningkatan Kemampuan Membaca dan Memahami Teks Bahasa Inggris Melalui Teknik Skimming, Scanning Pada Mahasiswa STIT RU Semester II 2017/2018}

\section{Fitri Susanty}

other form of language. Sebuah teks dapat terjadi suatu interaksi antar penulis dan pembaca, kemudian pembaca mencoba untuk menangkap pesan. Ketika membaca informasi yang tidak kita butuhkan akan lewat begitu saja. Informasi yang masih belum siap kita cerna hanya akan ditampung, sampai siap untuk mencerna dan memori akan memunculkan kembali informasi tersebut. Tarigan (2008:7) menyatakan bahwa membaca adalah suatu proses yang dilakukan serta dipergunakan oleh pembaca untuk memperoleh pesan yang hendak disampaikan.

Di samping pengertian atau batasan yang telah disampaikan diatas, membaca dapat diartikan sebagai suatu metode yang kita pergunakan untuk berkomunikasi dengan diri kita sendiri. Kegiatan membaca adalah komunikasi tulisan yang merupakan suatu kebutuhan penting dalam kehidupan sehari- hari di zaman modern yang penuh dengan kemajuan terutama dibidang informasi. Pesatnya kemajuan ilmu pengetahuan dan teknologi mendorong tersebarnya informasi secara cepat. Berbagai hasil cetakan diedarkan setiap hari dengan bidang dan topik yang berbeda-beda, memerlukan perhatian untuk dikaji guna menambah wawasan pengetahuan. Kemampuan membaca secara efektif dan efisien sangat dibutuhkan untuk bisa menyerap berbagai informasi atau pengetahuan ini, yang berbeda kepentingan bagi masing- masing pembaca.

Pemahaman tentang kalimat-kalimat itu meliputi pula kemampuan menggunakan teori tentang hubungan-hubungan struktural antarkalimat. Hubungan-hubungan struktural yang penting untuk memahami makna kalimat itu tidak hanya diberikan dalam struktur luar, tetapi juga diberikan dalam struktur isi kalimat. Pemahaman kalimat tidak akan dapat dilakukan dengan baik tanpa dukungan pemahaman atas hubungan isi antar kalimat tersebut. Untuk itu, agar memiliki keterbacaan yang tinggi, kalimat yang disusun dalam suatu wacana harus selalu memperhatikan unsur struktur luar, struktur isi, dan hubungan antar keduanya.Tulisan yang banyak mengandung kata yang tidak umum lebih sulit dipahami daripada yang menggunakan kosakata sehari-hari. Tentang hal ini telah dijelaskan pada penjelasan tentang kosakata baca. Demikian pula, bangun kalimat yang panjang dan kompleks akan menyulitkan pembaca yang tingkat perkembangan usianya berbeda.Uraian-uraian di atas mengimplikasikan bahwa penyusunan bacaan yang menurut pengarang sudah sesuai dengan tingkat perkembangan usia anak, namun tanpa mengindahkan penguasaan kosakata dan kalimat yang digunakan dalam suatu wacana yang mereka kenal, maka bacaan tersebut akan gagal dalam hal keterbacaannya.

Ada yang berpendapat bahwa panjang kalimat sebagai unsur utama yang menyebabkan timbulnya kesulitan dalam kegiatan membaca. Oleh karena itu, panjang kalimat dijadikan alat ukur tingkat keterbacaan sebuah wacana, dan biasanya dijadikan unsur utama dalam formulaformula keterbacaan. Kalimatkalimat yang kompleks pada umumnya panjang-panjang. Menurut susunan kalimatnya, kalimat tunggal lebih mudah dipahami maknanya atau maksudnya 
Volume 4 Nomor 1 Edisi Juni 2019

P-ISSN : 2541-3686

daripada kalimat majemuk. Hal ini disebabkan kalimat majemuk lebih rumit daripada kalimat tunggal.

Dari pendapat para ahli di atas tentang pengertian, tujuan, proses, dan pembelajaran membaca, serta pemahaman dapat disimpulkan bahwa pemahaman bacaan adalah pengertian yang diperoleh dari aktivitas membaca. Aktivitas ini melibatkan pembaca, teks, dan isi pesan yang disampaikan penulis. Seseorang dapat dikatakan memahami bacaan apabila ia telah mendapatkan informasi atau pesan yang disampaikan oleh penulis, baik tersurat maupun tersirat.

Rahim (2005;23) menyatakan bahwa prinsip-prinsip membaca yang paling mempengaruhi pemahaman bacaan, sebagai berikut:

Pemahaman merupakan proses konstruktivis sosial seperti;

- Teori kontruktivis menyatakan bahwa pemahaman dan penyusunan bahasa sebagai suatu proses membangun.

- Keseimbangan kemahiraksaraan adalah kerangka kerja kurikulum yang membantu perkembangan pemahaman.

- Guru membaca secara profesional (unggul) mempengaruhi proses belajar..

- Membaca hendaknya terjadi dalam konteks yang bermakna. dukungan yang penuh dari gurunya.

- $\quad$ Siswa menemukan manfaat membaca yang berasal dari berbagai teks pada berbagai tingkat.

- Pengikutsertaan adalah suatu faktor kunci pada proses pemahaman.

- Pengikutsertaan merupakan faktor kunci dalam proses Strategi dan keterampilan pemahaman bisa diajarkan.

- Asesmen yang dinamis menginformasikan pembelajaran membaca pemahaman.

Proses belajar terdiri dari proses yaitu penerimaan dan proses penemuan. Teori belajar bermakna Ausubel ini sangat dekat dengan inti pokok konstruktivisme. Teori ini menekankan pentingnya siswa mengasosiasikan pengalaman, fenomena dan fakta-fakta baru kedalam sistem pengertian yang telah dimiliki Ausubel. Guru harus dapat mengembangkan potensi kognitif siswa melalui proses belajar yang bermakna. Aktivitas belajar siswa akan bermanfaat kalau mereka banyak dilibatkan dalam kegiatan secara langsung.

\section{Kemampuan Memahami Teks}

Kemampuan adalah faktor penting dalam meningkatkan produktifitas, kemampuan berhubungan dengan pengeahuan (knowledge) dan keterampilan (skill) yang dimiliki seseorang (Ridwan 2005:14). kemampuan yang didasari oleh kreatifitas dan keterampilan adalah proses mental yang diarahkan untuk mencapai tujuan tertentu. Keterampilan membaca dan kemampuan memahami bacaan adalah dua hal yang saling berhubungan dimana kemampuan seseorang dapat dilihat dan keterampilan yang diwujudkan melalui tindakannya. Berdasarkan beberapa teori tersebut dapat disimpulkan bahwa kemampuan Membaca adálah kemampuan 


\section{Peningkatan Kemampuan Membaca dan Memahami Teks Bahasa Inggris Melalui Teknik Skimming, Scanning Pada Mahasiswa STIT RU Semester II 2017/2018}

Fitri Susanty

memahami, mengenal, mengidentifikasi,menganalisa, mengevaluasi dan menyimpulkan informasi dan pihak lain melalui sarana tulisan.

Memahami menurut Sadiman (2011:43) adalah suatu kemampuan seseorang dalam mengartikan, menafsirkan, menerjemahkan, atau menyatakan sesuatu dengan caranya sendiri tentang pengetahuan yang pernah diterimanya. Menurut Sadiman (2011: 47) Implementasi kemampuan memahami teks adalah sbb :

1. Kemampuan mengklasifikasi pola - pola objek

Seorang yang normal adalah orang yang mampu dalam mengklasifikasikan stimulasi-stimulasi yang tidak identik ke dalam satu kelas atau rumpun

2. Kemampuan beradaptasi (kemampuan belajar)

Kemampuan beradaptasi merupakan suatu kemampuan yang harus manusia miliki dalam kehidupannya dan kemampuan beradaptasi ini menentukan inteligensi atau kecerdasan seseorang apakah inteligensinya tinggi atau rendah 3. Kemampuan menalar secara deduktif

3. Kemampuan logika

Yaitu kemampuan menalar atau melogikan sesuatu dari kesimpulan menjadi paparan yang detail

4. Kemampuan menalar secara induktif Yakni kemampuan penalaran atau melogikakan sesuatu yang berupa paparan atau penjelasan menjadi suatu kesimpulan yang mewakili

5. Kemampuan mengembangkan konsep Yaitu kemampuan seseorang memahami suatu cara kerja objek atau fungsinya dan kemampuannya bagaimana menginterpretasikan suatu kejadian

6. Kemampuan memahami

Kemampuan memahami adalah kemampuan seseorang dalam melihat adanya hubungan atau relasi didalam suatu masalah dan kegunaan - kegunaan hubungannya bagi pemecahan masalah tersebut.

\section{Metode Skimming dan Scanning}

\section{Skimming}

Adalah suatu teknik membaca dengan kecepatan tinggi untuk mencari hal hal yang penting atau ide pokok dari suatu bacaan. Keterampilan membaca yang sangat berguna ialah skimming. Yang melibatkan pembaca sepintas dan cepat untuk mendapatkan kesan keseluruhan dan umum. Beberapa situasi yang menuntut penggunaan skimming adalah :

1. Memeriksa sebuah bab dalam buku, sebelum mempelajarinya secara serius agar memperoleh sebuah gagasan tentang cakupan umum bab tersebut.

2. Menyampel beberapa halaman novel atau karya tulis jenis lain untuk menentukan apakah karya tulis tersebut merupakan bacaan yang bernilai. 
P-ISSN : 2541-3686

3. Memeriksa secara epat sebuah artikel tentang isu kontroversial untuk menemukan pandangan pengarang, tanpa memperhatikan argumen pengarang yang spesifik.

4. Memeriksa bahan bacaan untuk menilai apakah bacaan tersebut mengandung jenis inormasi yang sedang kita cari.

5. Meneliti bahan bacaan untuk menentukan apakah bacaan tersebut dapat dipahami ataukah terlalu sulit.

Dalam skimming ini pembaca harus memiliki tujuan yang spesiik. Pengajar dapat mengatur kegiatan membaca sebagai berikut:

1) Meminta peserta didik memeriksa sebuah buku dan menyuruh memberitahukan apakah peserta didik tersebut ingin membacanya.

2) Menyuruh peserta didik memeriksa tiga buku dan menemukan salah satu yang mengandung legenda

3) Meminta peserta didik memeriksa buku bacaan untuk menilai apakah buku bacaan tersebut terlalu sulit ataukah tidak baginya.

Sebagai halnya keterampilan-keterampilan lain dalam membaca, peningkatan efisiensi membaca skimming berjalan secara teratur bersama dengan praktis. Sebuah teknik skimming yang baik dilakukan dengan hanya membaca kalimat pertama pada setiap paragra, sedangkan untuk pendahuluan dan kesimpulan atau ringkasan dibaca lebih teliti.

Langkah-langkah membaca skimming

1. Membuat pertanyaan tentang apa yang akan kita cari dari suatu buku

2. Telusuri daftar isi atau kata pengantar, apakah informasi yang kita butuhkan itu ada.

3. Dengan penuh perhatian, telusuri dengan kecepatan tinggi setiap paragraf atau subbab yang anda hadapi.

4. Berhentilah ketika merasa menemukan apa yang anda cari

5. Bacalah dengan kecepatan normal, dan pahami dengan baik apa yang anda cari tersebut.

\section{Scanning}

Salah satu keterampilan kompherensif yang paling penting adalah kemampuan membaca sepintas secara cepat keseluruhan bahan bacaan. Ada dua macam cara membaca sepintas (leming, 1968). Salah satunya adalah membaca cepat untuk menemukan jawaban suatu pertanyaan yang sangat spesiik seperti nama, tanggal, nomor telepon, dan sebagainya. Cara membaca ini sering disebut scanning. Jadi scanning adalah suatu teknik membaca cepat unuk mendapakan suatu inormasi tanpa membaca yang lain-lainnya.

Praktik mempelajari cara melakukan scanning bagi inormasi tertentu dapat dilakukan dengan baik dengan menggunakan macam-macam bahan bacaan yang biasanya dibaca dengan melakukan scanning dalam kegiatan membaca fungsional.

Pakar mengenai scanning untuk memperoleh informasi tertentu telah mengembangkan keterampilan khusus yang berbeda dangan cara membaca yang 
Peningkatan Kemampuan Membaca dan Memahami Teks Bahasa Inggris Melalui Teknik Skimming, Scanning Pada Mahasiswa STIT RU Semester II 2017/2018

Fitri Susanty

lain. Selama menggerakkan mata secara cepat melihat keseluruhan materi bacaan, pembaca tidak menyerap makna tetapi hanya mengenali bahwa hal-hal yang dicarinya, tampaknya hal itu secara jelas seolah-olah tercetak tebal. Beberpa orang dapat mencapai kecepatan yang hampir idak dapat dipercaya dengan melakukan scanning.

Dalam kehidupan sehari-hari scanning digunakan antara lain untuk :

1. Mencari nomor telepon

2. Mencari kata pada kamus

3. Mencari entri pada indeks

4. Mencari amgka-angka statistik

5. Mencari acara televisi

6. Mencari daftar perjalanan.

Langkah-langkah membaca scanning, jika anda ingin memperoleh hasil yang memuaskan dari teknik membaca cepat ini, ikutilah langkah-langkah berikut ini :

1. Lihatlah datar isi dan kata pengantar secara sekilas

2. Telaah secara singkat latar belakang penulisan buku

3. Baca bagian pendahuluan secara singkat

4. Cari dalam daftar isi bab-bab yang penting.

5. Baca bagian kesimpulan (jika ada)

6. Lihat secara sekilas daftar pustaka, daftar indeks, atau apendiks.

\section{Tujuan dan Manfaat Skimming dan Scanning}

Skimming dan scanning merupakan teknik membaca cepat yang sering dilakukan oleh pembaca. Kedua teknik ini sebenarnya sangat ungsional terutama dalamkehidupan sehari-hari.

Suatu keterampilan membaca yang diatur secara sistematis untuk mendapatkan hasil yang efisien untuk berbagai tujuan, seperti berikut ini:

1. Untuk mengenali topik bacaan

2. Untuk mengetahui pendapat orang

3. Untuk mengetahui organisasi penulisan

4. Untuk mendapatkan bagian penting yang kita perlukan tanpa membaca keseluruhan

5. Untuk penyegaran apa yang pernah kita baca.

Adapun manfaat itu anatara lain :

1. Dapat mencari suatu informasi khusus yang diperlukan dari sebuah teks bacaan atau buku secara cepat dan efisien

2. Dapat menjelajahi banyak halaman buku dalam waktu yang singkat

3. Tidak terlalu banyak membuang-buang waktu untuk mencari sesuatu yang diinginkan dari buku, khususnya tindakan yang tidak menunjang terhadap pencarian inormasi tersebut. 


\section{Metode Penelitian}

\section{Jenis Penelitian}

Penelitian ini menggunakan teknik Penelitian Tindakan Kelas (Classroom Action Reserarch). Dalam bagian ini diuraikan tentang tempat dan waktu penelitian, jenis penelitian, gambaran subyek penelitian, teknik pengumpulan data dan teknik analisis data. Teknik skimming dan scanning ini dipilih untuk memperbaiki kualitas pembelajaran. Masalah penelitian yang harus dipecahkan berasal dari persoalan praktik pembelajaran di kelas. Oleh karena itu penelitian tindakan kelas bertujuan untuk memperbaiki praktik pembelajaran yang seharusnya dilakukan oleh seorang guru. Penelitian tindakan kelas dilakukan secara focus pada masalah penelitian, perencanaan tindakan, pelaksanaan tindakan dan observasiinterpretasi, analisis serta refleksi.

\section{Indikator Keberhasilan}

Penelitian tindakan akan berakhir apabila indikator yang telah ditentukan tercapai yaitu:

- Perencanaan pembelajaran keterampilan membaca dengan teknik skimmingscanning dapat dinyatakan berhasil jika ada peningkatan nilai dari siklus I ke siklus II.

- Siklus peningkatan kemampuan mahasiswa dapat dinyatakan berhasil jika mahasiswa yang tuntas belajarnya meningkat dari siklus ke siklus. Siklus dihentikan jika siswa tuntas belajarnya telah mencapai $75 \%$.

\section{Hasil Penelitian Dan Pembahasan}

\section{- Proses Perencanaan Pembelajaran}

Penyusunan materi ajar Bahasa Inggris dengan menggunakan teknik skimmingscanning adalah suatu perencanaan pembelajaran yang disusun berdasarkan SILABUSyang ada di Sekolah Tinggi Ilmu Tarbiyah Raudhatul Ulum.

\section{- Sistem Evaluasi}

Untuk mengetahui hasil belajar kognitif kemampuan pemahaman membaca, diakhir tiap siklus diberikan tes esai. Pada siklus pertama diberikan sebanyak 5 soal. Pada siklus kedua terdapat esai dimana mahasiswa harus menjawab dengan berupa penjelasan berdasarkan informasi yang diperoleh.. Evaluasi digunakan untuk menentukan nilai atau hasil belajar mahasiswa. Kegiatan akhir penajar memberi penguatan dan pemantapan materi yang bertolak dari permasalahan. Tes dilakukan untuk mengetahui penguasaan materi setelah pembelajaran pemahaman membaca melalui pembelajaran skimming-scanning.

Dalam penelitian ini, alat ukur yang digunakan untuk mengukur kemampuan pemahaman membaca mahasiswa adalah tes pemahaman membaca dalam bentuk soal esai. Berdasarkan hasil analisis soal pemahaman membaca yang dilakukan 
Peningkatan Kemampuan Membaca dan Memahami Teks Bahasa Inggris Melalui Teknik Skimming, Scanning Pada Mahasiswa STIT RU Semester II 2017/2018

Fitri Susanty

didapat data bahwa nilai rata-rata pada Siklus I sebesar 6,5 dan pada Siklus II sebesar 8,5 .

\section{- Pemahaman Membaca}

Pemahaman membaca yang dihasilkan pada siklus pertama mahasiswa yang tuntas mencapai 12 atau $50 \%$ dari 24mahasiswa. Nilai rata-rata mencapai 6,5 dan siklus pertama sudah mencapai ketuntasan. Siklus kedua mahasiswa yang tuntas mencapai 24 mahasiswa atau $100 \%$ dari 24 siswa. Nilai rata-rata mencapai 8,5 sehingga siklus kedua menalami kenaikan nilai rata-rata dan jumlah mahasiswa yang tuntas.

\section{Simpulan}

- Perencanaan pembelajaran bahasa Inggris dengan menggunakan skimmingscanning dapat meningkatkan kemampuan membaca dan memahami pada siswa Pada hasil penelitian nilai rata-rata pada siklus 1 mencapai nilai rata-rata 6,5 sehingga dapat disimpulkan nilai yang dihasilkan cukup baik sedangkan nilai rata-rata pada siklus 2 mencapai 8,5 sehingga dapat disimpulkan bahwa nilai yang dihasilkan sangat baik.

- kemampuan membaca dan memahami mahasiswa mengalami peningkatan setelah mahasiswa dibelajarkan dengan menggunakan teknik skimmingscanning. Peninkatan kemampuan yang dihasilkan pada siklus pertama siswa yang tuntas mencapai 12 atau 50\% dari 24 siswa. Nilai rata-rata mencapai 6,5 dan siklus pertama sudah mencapai ketuntasan. Siklus kedua mahasiswa yang tuntas mencapai 24 siswa atau 100\% dari 24 siswa. Nilai rata-rata mencapai 8,5 sehingga siklus kedua sudah mencapai ketuntasan.

\section{Saran}

Berdasarkan simpulan diatas, maka saran yang diajukan adalah sebagai berikut:

Untuk Pengajar:

- Perlu mengembangkan bahan ajar dengan menggunakan teknik skimmingscanning

- Menggunakan teknik skimmingscanning dalam pembelajaran bahasa Inggris terutama untuk meningkatkan kemampuan membaca dan memahami karena dari hasil penelitian ini diketahui bahwa skimming-scanning dapat meningkatkan kemampuan membaca dan memahami.

Untuk Pihak Lembaga Pendidikan:

- Hendaknya perlu dikembangkan pembelajaran bahasa Inggris dengan menggunakan teknik skimmingscanning untuk pokok bahasan lain bahkan mata pelajaran lain yang memungkinkan. 
RAUDHAH Proud To Be Professionals qurnal Tarbiyak7slamiyak

Volume 4 Nomor 1 Edisi Juni 2019

P-ISSN : 2541-3686

- Memberi dorongan kepada pengajar dalam mengambangkan pembelajaran dengan menggunakan teknik skimming-scanning. 
Peningkatan Kemampuan Membaca dan Memahami Teks Bahasa Inggris Melalui Teknik Skimming, Scanning Pada Mahasiswa STIT RU Semester II 2017/2018 Fitri Susanty

\section{DAFTAR PUSTAKA}

Admin. 2012. Teknik Membaca Cepat Skimming dan Scanning. Jakarta: Atmajaya Djamarah. 2002. Psikologi Belajar. Jakarta: Rineka Cipta.

Howart,P.2006. Making Reading Communicative.Http://academic.cuesta.edu.html. diakses selasa 30 Noember 2018.

Putra.2011. PengertianSkimming dan Scanning. Http://penasehatcintae.blogspot.co.id. Diakses tanggal 23 Mei 2019

Rahim.2005.Kemampuan Efektif Membaca.http://file.upi.edu/Direktori/FPBS/JUR

•_PEND._BAHASA_DAERAH/195901191986011USEP_KUSWARI/Kemampuan_Efe ktif_Membaca.pdf.Diakses tanggal 2 Deember 2018

Ridwan.2005. Metode dan Teknik Penyusunan Tesis. Bandung: Alfabeta.

Sadiman. 2011. Definisi Pemahaman.http://www.masbied.com/ 2011/09/02/definisipemahamanmenurut-para-ahli/

Setiawan, Agus.2001. Baca Kilat-Kiat Membaca 1 halaman/Detik. Jakarta:

Gramedia. $\quad$ http://merahitam.com/teknikmembaca-cepat-skimmingdanscanning.html/diakses tanggal 2Deember 2018 